\title{
A Study to Determine the Effect of Egg Albumin Dressing On Peristomal Wound Healing of the Colostomy Patients in a Selected Hospital, Kolkata, West Bengal
}

\author{
Ms. Rimi Chakraborty ${ }^{1}$ | Dr Arpan Dutta Roy ${ }^{2}$ | Dr Sayantan Ghosh ${ }^{3^{*}}$ | Dr Pankaj \\ Kumar Singh $^{4}$ | Dr. Prolay Paul ${ }^{5}$
}

\begin{abstract}
${ }^{1} \mathrm{M}$ Sc. Critical Care Nursing WBUHS, Emergency and Disaster Nursing (INC, New Delhi), BLS, ACLS\& PALS Instructor, American Heart and Stroke Association MBA Hospital Administration, ICFAI, FCCS, Society of Critical Care Medicine (USA) NABH Internal Assessor (POI of NABH 5th Edition), QCI, CPHIC in Basic Infection Control, $\mathrm{CAHO}$

${ }^{2}$ Chief of Clinical Pharmacology Ruby General Hospital Certified NABH Assessor (QCI) HOPE Doctor of Pharmacy (PB) Clinical Research, (PhD.) Pharmacology Certified GCP, ACLS, Pharmacovigilance, NABH assessor

${ }^{3}$ Pharm D Intern Department of Pharmacy Practice Sri Adichunchanagiri College of Pharmacy, Karnataka

${ }^{4} \mathrm{MBBS}$, DNB Emergency Medicine Attending Consultant Department of Emergency Medicine Ruby General Hospital Kolkata

${ }^{5}$ Pharm D Intern Department of Pharmacy Practice Sri Adichunchanagiri College of Pharmacy Karnataka
\end{abstract}

\section{Abstract}

The researcher conducted a quasi experimental study to evaluate the effect of egg albumin dressing on peristomal wound healing in a selected hospital, Kolkata, with the objectives to assess the peristomal skin condition of colostomy patients before treatment, to evaluate the effect of egg albumin dressing on healing of peristomal area and reduction of pain, to find out the association between the peristomal wound healing and selected variables. The final study was conducted at Curzon ward, Victoria ward of SSKM hospital, Kolkata. Ethical permission was sought out from Ethical Committee of SSKM hospital, Kolkata. Informed consent was taken from all respondents. The sample was selected according to their selected criteria. The sample selection was done by purposive sampling. They were randomly assigned into two groups (experimental and control group) in 1:1 ratio. The study concluded with its limitations, implications and recommendations for conducting a study may be conducted for a longer duration of observation with the treatment.

Keywords: Albumin Dressing, Peristomal Wound Healing, Colostomy Patients, Egg Albumin

Copyright : (C) 2021 The Authors. Published by Publisher. This is an open access article under the CC BY-NC-ND license (https://creativecommons.org/licenses/by-nc-nd/4.0/).

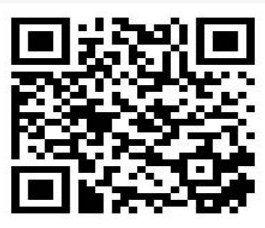




\section{1 | INTRODUCTION}

$\mathrm{A}$ ccording to the WHO reports in 2012, cancer is a leading cause of death worldwide, accounting for 8.2 million deaths. Amongst the most common causes of cancer death, about 694000 are from colorectal cancer. Most of the operable colorectal cancers require a surgical procedure called colostomy.

A colostomy is major surgery that creates an opening (known as a "stoma") in the colon to permit waste to exit outside the body into a pouch attached to the abdomen. Generally, in a colostomy, part of or the entire colon is removed. A colostomy may be permanent or temporary, depending on the medical condition that has necessitated the surgery. A permanent colostomy is customarily performed when the rectum or most of the colon is removed. (1)

The main purposes of a wound dressing are, to clean the site, absorb exudates, if any, ease pain and provide protection from infection. The wound dressing should ideally fulfill some primary and secondary requirements. (2)

The primary requirements would be that the dressing is free of toxic or irritant extractable, should not release particles or non-biodegradable fibres into the wound, should form an effective bacterial barrier, forms an effective water-resistant seal to the periwound skin, but is easily removable without causing trauma or skin stripping should be able to maintain the wound and the surrounding skin in an optimum state of hydration, provide protection to the periwound skin from potentially irritant wound exudates and excess moisture, produce minimal pain during application or removal as a result of adherence to the wound surface and maintain the wound at the optimum temperature and $\mathrm{pH}$. The secondary requirements should include antimicrobial activity, ability to remove or inactivate proteolytic enzymes in chronic wound fluid, possess haemostatic activity and have effective wound debriding activity. (3)

\section{2 | NEED OF THE STUDY}

One of the main types of stoma is colostomy, which has a risk of forming sore on the peristomal skin. Through the stomas, feces and body fluid are collected in the stoma appliance. The stoma appliance is attached to the peristomal skin with adhesive. As there is a chance of continuous seepage of feces and body fluid through this stoma there is a high chance of skin excoriation at peristomal region due to the corrosiveness of that feces and body fluid. Also the continuous pressure and friction caused due to the adhesive of the stoma appliance contribute to the chances of excoriation of the peristomal skin. The severity of the excoriation depends primarily on these factors. It is essential to ensure that the skin surface, on which the appliance is attached, is free from breaks or soreness as this might lead to appliance leakage.

Generally enterostomal therapist takes care of these stomas in the post operative period. As there is an inadequate number of enterostomal therapist, the general nurse also has a vital role to take care of the patient with a stoma. Taking care of the patient with any ostomy is indeed a challenge to any nurse.

The investigator during her clinical experience noticed that the peristomal skin excoriation is very common in the patient having colostomy and different types of dressing, commercially available in the market viz, ostomy powder, ostomy paste, hydrocolloid based appliances, etc are applied to reduce peristomal skin complications. The investigator, considering the increasing number of cases from different economic backgrounds, has felt that there is a need to look into alternative dressing materials.

Use of egg white for treatment and healing of wounds was an old Roman technique for treating gunshot wounds. Egg white constitutes about $20-25 \%$ of the

Supplementary information The online version of this article (https://doi.org/10.15520/jemro.v4i04.40 9) contains supplementary material, which is available to authorized users.

Corresponding Author: Dr Sayantan Ghosh Pharm D Intern Department of Pharmacy Practice Sri Adichunchanagiri College of Pharmacy, Karnataka Email: gsayantan26@gmail.com 


\section{CURRENT MEDICAL RESEARCH AND OPINION}

egg. The egg white is composed of proteins and minerals. Different types of proteins are present in egg white.

Some of them are Ovalbumin, Conalbumin, Ovamucoid, Ovomucin, Lysozyme, Avidin,

Ovoglobulin, Ovoinhibitor. It also contains minerals like Sulphur, which has antibacterial and antiinflammatory properties and Copper which is toxic to bacteria and also used in a number of rejuvenating and skin revitalizing treatments. These properties of egg albumin make it suitable to be used in topical application in medical dressing.

Thus the investigator thought that topical application of egg white dressing may be an effective healing agent for peristomal wounds.

\section{3 | OBJECTIVES -}

- To evaluate the effect of egg albumin dressing on healing of the peristomal skin area and reduction of pain among experimental group of colostomy patients.

- To assess the peristomal skin condition among experimental group of colostomy patients before treatment.

- To assess the peristomal skin condition among control group of colostomy patients before treatment.

- To find out the association between the peristomal wound healing and selected sample characteristics.

\section{4 | STUDY CRITERIA-}

Inclusion Criteria-

- Colostomy patients admitted in the surgical ward on their 5 th postoperative day onward

- Patients who are willing to participate in the study
- Adult patient $>18$ years of age irrespective of their disease condition.

Exclusion Criteria-

- Known allergic condition to egg albumin

\section{5 | MATERIALS \& METHOD-}

Study Type-

The Study was a Quasi experimental research approach.

Study Design

The design adopted for this study is pre-test post-test control group time series design.

Operational Definitions-

Colostomy Patient - In this study, colostomy patient refers to patients more than 18 years age, admitted in the surgical ward of the selected hospital on the 4 th postoperative day of permanent or temporary colostomy.

Peristomal skin - It refers to the area surrounding the stoma where appliance is attached.

Egg albumin dressing - It refers to the direct application of the raw egg white portion with the help of sterile gauge piece, once in a day, on alternate days, for a total of three times, on the peristomal skin, after cleaning the region with $0.9 \%$ normal saline

Effect - It refers to weather the desired effect of egg albumin dressing has achieved or not and is measured by healing score.

Peristomal skin wound - Peristomal skin wound is assessed by modified Ostomy Skin Tool, the wound status is assessed through rating scale and will be measured by DET Scoring in terms of the discoloration, erosion, and tissue overgrowth. Table 1

Selected sample characteristics - Selected sample characteristics will include demographic profile (consist of age, sex, education, occupation, income), health assessment (height, weight BMI), illness profile (duration of illness, time taken to diagnose, duration of peristomal skin wound, cancer stage, nature of surgery, no of postoperative days in intensive care 
TABLE 1: Schematic representation of data collection instruments -

\begin{tabular}{|c|c|c|c|}
\hline $\begin{array}{l}\text { Tool } \\
\text { No }\end{array}$ & Name of the tool & Variables to be measured & Technique \\
\hline Tool-I & Semi-structured interview schedule & Demographic profile & Interview \\
\hline $\begin{array}{l}\text { Tool- } \\
\text { II }\end{array}$ & $\begin{array}{l}\text { Health assessment proforma Record } \\
\text { analysis } \\
\text { proforma }\end{array}$ & $\begin{array}{l}\text { Height, weight, BMI } \\
\text { Illness profile }\end{array}$ & $\begin{array}{l}\text { Measurement } \\
\text { Record analysis }\end{array}$ \\
\hline $\begin{array}{l}\text { Tool- } \\
\text { III }\end{array}$ & Modified Ostomy Skin Tool & $\begin{array}{l}\text { Peristomal skin wound } \\
\text { status }\end{array}$ & Assessment \\
\hline $\begin{array}{l}\text { Toll- } \\
\text { IV }\end{array}$ & Visual analogue scale & Wound pain & Assessment \\
\hline
\end{tabular}

unit, presence of Diabetes mellitus, hypertension, feeding pattern, blood report of $\mathrm{HB} \%$, WBC, ESR).

Data Collection Procedure-

The final study was conducted at Curzon ward, Victoria ward of SSKM hospital. Kolkata.

Ethical permission was sought out from Ethical Committee of SSKM hospital, Kolkata. Informed consent was taken from all respondents. The sample was selected according to their selected criteria. The sample selection was done by purposive sampling .But randomly assigned into two groups (experimental and control group) in 1:1 ratio. First one was selected as experimental group and second one as control group. In this way 15 patients in the experimental group were selected and coded as E1, E2, E3, ..... E15 and another 15 patients in the control group were selected and coded as C1, C2, C3 .... C15.

The Data was Analysed-using

Section I- The findings related to the description of the demographic characteristics of the colostomy patients presented in frequencies and percentage distribution.

Section II A- The findings related to the description of the health assessment of the colostomy patients presented in frequencies and percentage distribution.

Section II B- The findings related to the description of the illness profile of the colostomy patients presented in frequencies and percentage distribution.

Section III- The findings related to the pre intervention score of experimental group and control group by mean, median, and standard deviation.

Study Site
The study was conducted at the surgical ward of the SSKM Hospital, Kolkata.

\section{6 | RESULTS-}

Tables 2, 3, 4, 5, 6, 7, 8, 9, 10, 11, 12, 13, 14, 15, 16, 17 and 18

Section-II A Finding related to the description of the health assessment of the colostomy patients

Section-III Findings related to the pre intervention peristomal skin wound score of experimental group and control group by mean, mean difference and standard deviation.

Section-IV Finding related to the distribution of the colostomy patients according to the preobservation pain score observed by VAS

Section V Effectiveness of egg albumin dressing for Peristomal skin wound healing.

There is a significant difference of mean score of peristomal skin wound discoloration in colostomy patients in experimental group before and after application of egg albumin dressing as measured by modified ostomy skin tool at 0.05 level of significance.

There is a significant difference of mean score of peristomal skin wound erosion in colostomy patients in experimental group before and after application of egg albumin dressing as measured by modified Ostomy Skin Tool at 0.05 level of significance.

There is a significant difference of mean score of peristomal skin wound tissue overgrowth in colostomy patients in experimental group before and 


\section{GURRENT MEDICAL RESEARCH AND OPINION}

TABLE 2: Frequency and percentage distribution of the colostomypatients according to their age, sex and educational qualification. $n=30(15+15)$

\begin{tabular}{|c|c|c|c|c|}
\hline \multirow{2}{*}{ Camnlo Charartarictirc } & \multicolumn{2}{|c|}{ Experimental Group } & \multicolumn{2}{|c|}{ Control Group } \\
\hline & $\begin{array}{l}\text { Frequency } \\
\text { (f) }\end{array}$ & Percentage (\%) & $\begin{array}{l}\text { Frequency } \\
\text { (f) }\end{array}$ & Percentage (\%) \\
\hline \multicolumn{5}{|l|}{ Age (In years) } \\
\hline $18-30$ & 1 & 6.7 & 1 & 6.7 \\
\hline $31-50$ & 10 & 66.7 & 11 & 73.3 \\
\hline $51-70$ & 4 & 26.7 & 3 & 20 \\
\hline \multicolumn{5}{|l|}{ Sex } \\
\hline Male & 8 & 53.3 & 10 & 66.7 \\
\hline Female & 7 & 46.7 & 5 & 33.3 \\
\hline \multicolumn{5}{|l|}{ Educational Qualification } \\
\hline Primary & 8 & 53.3 & 9 & 60.0 \\
\hline Secondary & 5 & 33.3 & 3 & 20.0 \\
\hline Higher Secondary \& Above & 2 & 13.3 & 3 & 20.0 \\
\hline
\end{tabular}

TABLE 3: Frequency and percentage distribution of thecolostomy patients according to their occupation, monthly family income anddiagnosis $n=30(15+15)$

\begin{tabular}{|c|c|c|c|c|}
\hline \multirow{2}{*}{ Sample Characteristics } & \multicolumn{2}{|c|}{ Experimental Group } & \multicolumn{2}{|c|}{ Control Group } \\
\hline & $\begin{array}{l}\text { Frequency } \\
\text { (f) }\end{array}$ & Percentage (\%) & $\begin{array}{l}\text { Frequency } \\
\text { (f) }\end{array}$ & Percentage (\%) \\
\hline \multicolumn{5}{|l|}{ Occupation } \\
\hline Service & 2 & 13.3 & 3 & 20 \\
\hline Daily labor & 5 & 33.3 & 4 & 26.7 \\
\hline Business & 8 & 53.3 & 8 & 53.3 \\
\hline \multicolumn{5}{|l|}{ Monthly Family Income } \\
\hline$<4000 /-$ & Nil & - & 1 & 6.7 \\
\hline 4000/- and above & 15 & 100 & 14 & 93.3 \\
\hline \multicolumn{5}{|l|}{ Diagnosis } \\
\hline CA Rectum & 7 & 46.7 & 6 & 40 \\
\hline CA Colon & 8 & 53.3 & 9 & 60 \\
\hline
\end{tabular}

after application of egg albumin dressing as measured by modified Ostomy Skin Tool at 0.05 level of significance.

There is a significant difference of mean post intervention score of Peristomal skin wound discoloration in colostomy patients in the experimental group getting egg albumin dressing than that of control group assumed to get conventional treatment at 0.05 level of significance.

There is a significant difference of mean post intervention score of peristomal skin wound erosion among colostomy patients in the experimental group getting egg albumin dressing than that of control group assumed to get conventional treatment at 0.05 level of significance.

There is a significant difference of mean post intervention score of Peristomal skin wound tissue overgrowth among colostomy patients in the experimental group getting egg albumin dressing than that of control group assumed to get conventional treatment at 0.05 level of significance.

Section VI: Effectiveness of egg albumin dressing for reducing degree of Peristomal skin wound pain. 
A Study to Determine the Effect of Egg Albumin Dressing On Peristomal Wound Healing of the Colostomy Patients in a Selected Hospital, Kolkata, West Bengal

TABLE 4: Frequency and percentage distribution ofcolostomy patients according to their height, weight and $\mathrm{BMI}$

\begin{tabular}{|c|c|c|c|c|}
\hline \multirow{2}{*}{$\begin{array}{l}\text { Sample } \\
\text { Characteristics }\end{array}$} & \multicolumn{2}{|c|}{ Experimental Group } & \multicolumn{2}{|l|}{ Control Group } \\
\hline & $\begin{array}{l}\text { Frequency } \\
\text { (f) }\end{array}$ & Percentage (\%) & $\begin{array}{l}\text { Frequency } \\
\text { (f) }\end{array}$ & Percentage (\%) \\
\hline \multicolumn{5}{|l|}{ Height in $\mathrm{cms}$} \\
\hline$>137-150$ & 6 & 40 & 7 & 46.7 \\
\hline$>150-163$ & 7 & 46.7 & 6 & 40 \\
\hline$>163-176$ & 2 & 13.3 & 2 & 13.3 \\
\hline \multicolumn{5}{|l|}{ Weight in kg } \\
\hline $40-45$ & 4 & 26.7 & 5 & 33.3 \\
\hline $45-50$ & 7 & 46.7 & 5 & 33.3 \\
\hline $50-55$ & 3 & 20 & 3 & 20 \\
\hline $55-60$ & Nil & - & 1 & 6.6 \\
\hline $60-65$ & 1 & 6.6 & 1 & 6.6 \\
\hline \multicolumn{5}{|l|}{$\mathrm{BMI}$} \\
\hline Normal & 10 & 66.7 & 9 & 60 \\
\hline Low & 5 & 33.3 & 6 & 40 \\
\hline
\end{tabular}

TABLE 5: Frequency and percentage distribution ofcolostomy patients according to their cancer stage, type of surgery performedand no of days stay in ICU

\begin{tabular}{|c|c|c|c|c|}
\hline \multirow[t]{2}{*}{ Sample Characteristics } & \multicolumn{2}{|c|}{ Experimental Group } & \multicolumn{2}{|l|}{ Control Group } \\
\hline & $\begin{array}{l}\text { Frequency } \\
\text { (f) }\end{array}$ & Percentage (\%) & Frequency (f) & Percentage (\%) \\
\hline \multicolumn{5}{|l|}{ Cancer stage } \\
\hline Stage-I & 5 & 33.3 & 6 & 40 \\
\hline Stage-II & 6 & 40 & 6 & 40 \\
\hline Stage-III & 4 & 26.7 & 3 & 20 \\
\hline \multicolumn{5}{|c|}{ Types of surgery performed } \\
\hline Therapeutic & 15 & 100 & 15 & 100 \\
\hline Palliative & Nil & - & Nil & - \\
\hline \multicolumn{5}{|l|}{ No of days stay in ICU } \\
\hline 2 Day & Nil & - & 2 & 13.3 \\
\hline 3 Day & Nil & - & Nil & - \\
\hline None & 15 & 100 & 13 & 86.7 \\
\hline
\end{tabular}

There is a significant difference of mean Peristomal skin wound pain score among colostomy patients in experimental group before and after application of egg albumin dressing as measured by VAS at 0.05 levels of significance.

There is a significant difference of mean Peristomal skin wound pain score among colostomy patients in experimental group before and after application of egg albumin dressing as measured by VAS at 0.05 levels of significance.

There is a significant difference of mean post intervention score of pain among colostomy patients in the experimental group getting egg albumin dressing than that of control group assumed to get conventional treatment at 0.05 levels of significance. 
TABLE 6: Frequency and percentage distribution of colostomy patientsaccording to the presence of diabetes mellitus, hypertension and haemoglobinlevels

\begin{tabular}{|c|c|c|c|c|}
\hline \multirow[t]{2}{*}{ Sample Characteristics } & \multicolumn{2}{|c|}{ Experimental Group } & \multicolumn{2}{|c|}{ Control Group } \\
\hline & $\begin{array}{l}\text { Frequency } \\
\text { (f) }\end{array}$ & Percentage (\%) & $\begin{array}{l}\text { Frequency } \\
\text { (f) }\end{array}$ & Percentage (\%) \\
\hline \multicolumn{5}{|l|}{ Diabetes mellitus } \\
\hline Absent & 11 & 73.3 & 9 & 60 \\
\hline Present & 4 & 26.6 & 6 & 40 \\
\hline \multicolumn{5}{|l|}{ Hypertension } \\
\hline Absent & 15 & 100 & 12 & 80 \\
\hline Present & Nil & - & 3 & 20 \\
\hline \multicolumn{5}{|l|}{$\mathrm{Hb}$ level } \\
\hline Normal & 7 & 46.7 & 6 & 40 \\
\hline Below normal & 8 & 53.3 & 9 & 60 \\
\hline
\end{tabular}

TABLE 7: Frequency and percentage distribution of colostomy patientsaccording to their WBC count, ESR level and mode of feeding

\begin{tabular}{|c|c|c|c|c|}
\hline \multirow[t]{2}{*}{ Sample characteristics } & \multicolumn{2}{|c|}{ Experimental Group } & \multicolumn{2}{|c|}{ Control Group } \\
\hline & $\begin{array}{l}\text { Frequency } \\
\text { (f) }\end{array}$ & Percentage (\%) & $\begin{array}{l}\text { Frequency } \\
\text { (f) }\end{array}$ & Percentage (\%) \\
\hline \multicolumn{5}{|l|}{ White blood cell count } \\
\hline Above normal & 4 & 26.7 & 7 & 46.7 \\
\hline Normal & 11 & 73.3 & 8 & 53.3 \\
\hline \multicolumn{5}{|l|}{ ESR level } \\
\hline Above normal & Nil & - & Nil & - \\
\hline Normal & 15 & 100 & 15 & 100 \\
\hline \multicolumn{5}{|l|}{ Mode of feeding } \\
\hline Enteral & 15 & 100 & 15 & 100 \\
\hline Parental & Nil & - & Nil & - \\
\hline
\end{tabular}

TABLE 8: Mean, Mean Difference and Standard Deviation ofpre-intervention score of experimental and control group of colostomy patients

\begin{tabular}{lllll} 
Group & Domain & Mean & Mean D & SD \\
Experimental & Discolorati & 4.06 & & 0.99 \\
Control & & 4.06 & & 0.99 \\
Experimental & & 3.80 & \multirow{2}{*}{0.07} & 0.97 \\
Control & Erosion & 3.73 & & 0.98 \\
Experimental & Tissue & 2.26 & \multirow{2}{*}{0.07} & 0.92 \\
Control & over- & 2.33 & & 0.93 \\
\hline \multicolumn{5}{r}{ growth } \\
\end{tabular}


TABLE 9: Frequency and percentage distribution ofcolostomy patients according to the preintervention pain score observed byVAS

\begin{tabular}{|c|c|c|c|c|}
\hline \multirow{2}{*}{ Degree of Pain } & \multicolumn{2}{|c|}{ Experimental Group } & \multicolumn{2}{|c|}{ Control Group } \\
\hline & $\begin{array}{l}\text { Frequency } \\
\text { (f) }\end{array}$ & Percentage (\%) & $\begin{array}{l}\text { Frequency } \\
\text { (f) }\end{array}$ & Percentage (\%) \\
\hline Little Discomfort (1-2) & 1 & 6.7 & 1 & 6.7 \\
\hline Mild Pain (3-4) & 5 & 33.3 & 5 & 33.3 \\
\hline Moderate Pain (5-6) & 8 & 53.3 & 7 & 46.7 \\
\hline Severe pain (7-8) & 1 & 6.7 & 2 & 13.3 \\
\hline
\end{tabular}

TABLE 10: Mean, Mean Difference, SD, SE and Paired " $t$ "value of pre and post intervention colostomy skin wound discoloration score bymodified Ostomy Skin Tool in experimental Group $n=15$

\begin{tabular}{llllll} 
Observation & Mean & MD & SD & SE & 't' \\
Before treatment & 4.06 & 2.06 & 0.99 & 0.42 & $4.84 *$ \\
After treatment & 2.00 & & 1.31 & & \\
\hline$d f(14)=2.15, p<0.05$ & & & & &
\end{tabular}

TABLE 11: Mean, Mean Difference, SD, SE and Paired " $t$ "value of pre and post intervention colostomy skin wound erosion score bymodified Ostomy Skin Tool in experimental $n=15$

\begin{tabular}{llllll} 
Observation & Mean & MD & SD & SE & 't' \\
Before treatment & 3.8 & 2.00 & 0.97 & 0.42 & $4.69^{*}$ \\
After treatment & 1.8 & & 1.32 & & \\
\hline$d f(14)=2.15, P<0.05$ & & & & &
\end{tabular}

TABLE 12: Mean, Mean Difference, SD, SE and Paired " $t$ "value of pre and post intervention colostomy skin wound tissue overgrowth scoreby modified Ostomy Skin Tool in experimental Group

\begin{tabular}{llllll} 
Observation & Mean & MD & SD & SE & 't' \\
Before treatment & 2.26 & 1.66 & 0.92 & 0.28 & $5.80 *$ \\
After treatment & 0.6 & & 0.61 & & \\
\hline$d f(14)=2.15, p<0.05$ & & & & &
\end{tabular}

TABLE 13: Mean, Mean Difference, SD, SE and Unpaired " $t$ " value ofexperimental and control group post observation score of discoloration measuredby Modified Ostomy Skin Tool

\begin{tabular}{llllll} 
Group & Mean & MD & SD & SE & 't' \\
Experimental Group & 2.0 & -2.0 & 1.31 & 0.42 & $4.74 *$ \\
Control Group & 4.0 & & 0.96 & & \\
\hline$d f(28)=2.05, p<0.05$ & & & & &
\end{tabular}

TABLE 14: Mean, Mean Difference, SD and Unpaired " $t$ " valueof experimental and control group post observation score of erosion measured bymodified Ostomy Skin $n=30(15+15)$

\begin{tabular}{llllll} 
Variable & Mean & MD & SD & SE & 't' \\
Experimental Group & 1.8 & -1.8 & 1.32 & 0.43 & $4.16^{*}$ \\
Control Group & 3.6 & & 1.01 & & \\
\hline$d f(28)=2.05, p<0.05$ & & & & &
\end{tabular}




\section{CURRENT MEDICAL RESEARCH AND OPINION}

TABLE 15: Mean, Mean Difference, SD and Unpaired " $t$ " value ofexperimental and control group post observation score of tissue overgrowthmeasured by modified Ostomy Skin $n=30(15+15)$

\begin{tabular}{llllll} 
Variable & Mean & MD & SD & SE & 't' \\
Experimental Group & 0.6 & & 0.61 & 0.26 & $5.31^{*}$ \\
Control Group & 2.00 & -1.4 & 0.81 & & \\
\hline
\end{tabular}

$\mathrm{df}(28)=2.05, \mathrm{p}<0.05$

TABLE 16: Mean, Mean Difference, SD and Paired " $t$ " valueof pre and post Intervention peristomal skin wound pain score by VAS inexperimental Group $\mathrm{n}=15$

\begin{tabular}{llllll} 
Observation & Mean & MD & SD & SE & 't' \\
Before treatment & 5.2 & & 1.42 & 0.48 & $8.25^{*}$ \\
After treatment & 1.2 & 4.0 & 1.22 & & \\
\hline
\end{tabular}

$\mathrm{df}(14)=2.15, \mathrm{P}<0.05$

There is a significant difference of mean post intervention score of pain among colostomy patients in the experimental group getting egg albumin dressing than that of control group assumed to get conventional treatment at 0.05 levels of significance..

Section-VII Findings related to the association between peristomal skin wound healing and illness profile of the colostomy patients.

\section{7 | DISCUSSION AND CONCLUSION:}

The present study was likely to be supported by the study of Parkinson, 1999, who conducted a study and evaluated that the major proteins of albumen are ovalbumin, conalbumin (ovotransferrin), ovomucoid, lysozyme and ovomucin. Lysozyme which forms a chemical protection against microorganism, by dissolving the cell wall of bacteria, constitutes about $3.5 \%$ of the egg. This prompted the researcher to conduct this study with a desire to study the effect of application of egg albumin, in peristomal wound dressing, with respect to its healing of the wound.

The present study has revealed that satisfactory healing of the peristomal skin wound was achieved by the application of egg albumin dressing in terms of reduction of irritation in the wound area. Similar reports have been published in the study to determine the effect of cyanoacrylate protectant to manage peristomal skin irritation under ostomy skin barrier wafers conducted by Catherine T. Milne, Darlene
Saucier, Chenel Trevellini, Juliet Smith (2010). Additionally, their study also reported the adhesive properties of egg albumin which helped in effective sealing between the stoma appliance and the peristomal skin.

The present study has also revealed that healing of the peristomal skin wound was achieved by the application of egg albumin dressing in terms of tissue overgrowth, discolouration, and controlling tissue erosion. This is line with the reports published by Zou, C, Kobayshi, K and Kato (1991) who had observed the morphological changes in some cell types under the influence of egg white, suggesting that egg white may promote cell differentiation.

\section{REFERENCES}

1. Salvadalena GD. The incidence of stoma and peristomal complication during the first 3 months after stoma creation. Journal of Wound Ostomy Continence Nurse 2013 Jul-Aug; 40 (4): 400-6 ;.

2. Adham M, Abdou, Mujo K, Kenji S. Functional Proteins and Peptides of Hen's Egg Origin. Bioactive Food Peptides in Health and Disease 2013; ISBN: 978-953-51-0964-8. ;.

3. Robert E, Feeney and David A. The antibacterial activity of the egg white protein conalbumin. Journal of Bacteriology 1952 Nov; 64(5): 62943.; 
A Study to Determine the Effect of Egg Albumin Dressing On Peristomal Wound Healing of the Colostomy Patients in a Selected Hospital, Kolkata, West Bengal

TABLE 17: Mean, Mean Difference, SD, SE and Unpaired " $t$ "value of experimental and control group wound pain score measured by VAS $n=30$

\begin{tabular}{llllll} 
Group & Mean & MD & SD & SE & 't' \\
Experimental & 1.2 & & 1.22 & 0.45 & $6.16^{*}$ \\
Control & 4.0 & -2.8 & 1.26 & & \\
\hline df $(28)=2.05, P<0.05$ & & & &
\end{tabular}

TABLE 18: Chi-square to find out the association between selectedsample characteristics and Peristomal skin wound healing among colostomy patients $n=15$

\begin{tabular}{llll} 
Sample characteristics & $\begin{array}{l}\text { Post } \\
\text { score }\end{array}$ & observation & x2 \\
& $<$ Median & $\geq$ Median & value \\
BMI & 8 & 2 & 2.8 \\
Normal & 1 & 4 & \\
$\begin{array}{l}\text { Below normal } \\
\text { Diabetic Mellitus }\end{array}$ & 2 & 2 & 1.03 \\
$\begin{array}{l}\text { Present } \\
\text { Absent }\end{array}$ & 1 & 10 & \\
$\begin{array}{l}\text { Haemoglobin Level } \\
\text { Below normal }\end{array}$ & 3 & 5 & 1.87 \\
Normal & 6 & 1 & \\
$\begin{array}{l}\text { WBC Count } \\
\text { Above normal } \\
\text { Normal }\end{array}$ & 110 & 3 & 1.83 \\
\hline
\end{tabular}

How to cite this article: Chakraborty M.R., D.A.D.R., Ghosh D.S., Singh D.P.K., Paul D.P. A Study to Determine the Effect of Egg Albumin Dressing On Peristomal Wound Healing of the Colostomy Patients in a Selected Hospital, Kolkata, West Bengal. Journal of Current Medical Research and Opinion. 2021;886-894. https://doi. org/10.15520/jcmro.v4i04.409 